\title{
Bladder Cancer pT4b TNM Finding v8
}

National Cancer Institute

\section{Source}

National Cancer Institute. Bladder Cancer pT 4b TNM Finding v8. NCI Thesaurus. Code C140406.

Bladder cancer with extravesical tumor invading pelvic wall, abdominal wall. (from AJCC 8th Ed.) 